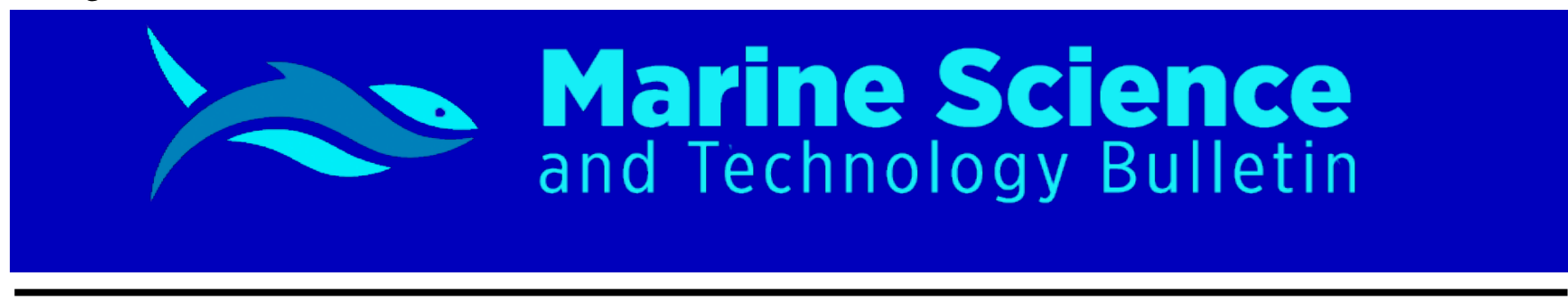

RESEARCH ARTICLE

\title{
The effects of EDTA on lead accumulation in tissues of Clarias gariepinus
}

\author{
Fahri Karayakar $^{1^{*}}$ (D) Adeviye Yavuz $^{1}$ (D) Bedii Cicik ${ }^{1}$ (D) \\ ${ }^{1}$ Mersin University, Faculty of Fisheries, Mersin, Turkey
}

\begin{tabular}{l} 
A R T I C L E I N F O \\
\hline Article History: \\
Received: 27.07 .2020 \\
Received in revised form: 10.09 .2020 \\
Accepted: 13.09 .2020 \\
Available online: 29.10 .2020 \\
$\quad$ Keywords: \\
Clarias gariepinus \\
Lead \\
EDTA \\
Interaction \\
Tissue \\
Accumulation
\end{tabular}

\begin{abstract}
A B S T R A C T
This study was intended to determine the lead accumulation levels in liver, gill, kidney, brain, and muscle tissues of Clarias gariepinus (African sharp tooth catfish) under the sole effect of lead (1.0 and $2.0 \mathrm{ppm}$ ) and combined with EDTA (Ethylene diamine tetraacetic acid) (2.0 and $4.0 \mathrm{ppm}$ ) for 7,15 , and 30 days. Inductively coupled plasma mass spectrometry (ICP-MS) was used to determine tissue lead levels, and the SPSS package program was used for statistical evaluation of the experimental data. No mortality was observed in fish over the time periods of the experiments, and concentrations were determined with lead only and with lead together with EDTA. At the end of the experimental periods, the presence of lead increased the metal accumulation in the tissues and organs examined when compared to the control, and, in terms of accumulation, a relationship was determined between the tissues in the order of gill $>$ kidney $>$ liver $>$ brain $>$ muscle. The effect of lead together with EDTA was reduced lead accumulation in tissues and organs when compared to the effect of lead only.
\end{abstract}

Please cite this paper as follows:

Karayakar, F., Yavuz, A., Cicik, B. (2021). The effects of EDTA on lead accumulation in tissues of Clarias gariepinus. Marine Science and Technology Bulletin, 10(1): 28-35.

\section{Introduction}

The disposal and poor management of toxic chemicals such as heavy metals negatively affect ecosystem integrity, environmental quality, and human health (Banaee et al., 2013). Heavy metals such as lead, cadmium, and mercury do not have any biological functions in animal organisms, while other heavy metals, such as copper, zinc, iron, and chromium, at low concentrations, are essential for metabolic processes. However, they are also toxic above a certain concentration range and can negatively affect all trophic levels throughout the food chain (Shukla et al., 2007).

Lead is a heavy metal widely used in various industrial applications, such as paint, storage batteries, and the automotive industry, as well as being naturally found in soil, water, and rocks (Khidr et al., 2012). Lead at high concentrations leads to accumulation in tissues and organs (Cicik et al., 2004), behavioral changes (Çiftçi et al., 2008), lordoscolosis and anomalies in pigmentation (Martinez et al., 2004), collapse of the immune system in fish (Vosylienè, 1999)

\footnotetext{
* Corresponding author

E-mail address: fkarayakar@mersin.edu.tr (F. Karayakar)
} 
and mutagenic, teratogenic, and carcinogenic effects and infertility in humans (Eisler, 2000).

Organic and inorganic complexes, such as EDTA, NTA (Nitrilotriacetic acid), DTPA (Diethylenetriamine pentaacetic acid), DFO (Deferoxamine), DFP (Deferiprone), zeolite, clinoptilolite, and chitosan, are widely used in aquatic systems to remove pollutants from the environment. A high capacity to form complexes with heavy metals and low biological degradability in aquatic systems are the main properties of chemicals used as chelators (Kedziorek and Bourg, 2000).

In fish, the liver accumulates metals at high concentrations regardless of the intake path, and, because the metal load in the liver is close to the concentration of the metal in the environment, it is very important in monitoring metal pollution in aquatic ecosystems (Jezierska and Witeska, 2006). Gills, which have vital functions such as respiration and osmoregulation, are the main target organs for toxic chemicals because they interact directly with the environment (Poleksic and Mitrovic-Tutundzic, 1994). In fish, kidneys function in maintaining homeostasis, as well as in removing nitrogencontaining metabolic waste materials and toxic substances from the body (Cengiz, 2006). The brain is a metabolically active organ that is highly sensitive to changes in energy metabolism (Soengas and Aldegunde, 2002). Although the muscle tissue in fish is not active in terms of metal accumulation, it constitutes the main consumable part of the fish, and it functions in the transmission of metal to humans through the food chain, so it is very important in terms of environment and human health (Jezierska and Witeska, 2006).

Although there are many studies on the accumulation and toxic effects of heavy metals in aquatic organisms, the studies on the effects of complexing agents on heavy metal toxicity are limited. Therefore, this study aimed to determine the levels of lead accumulation solely and of lead accumulation together with EDTA in the liver, gill, kidney, brain, and muscle tissues of C. gariepinus for periods of seven, fifteen, and thirty days.

\section{Material and Methods}

The research was carried out in the basic sciences research laboratory of the Mersin University Faculty of Fisheries Application Unit under controlled ambient conditions $(24 \pm 1$ ${ }^{\circ} \mathrm{C}$ fixed temperature, 12-hour dark/12-hour daylight photoperiod, central ventilation system).

C. gariepinus specimens of $68.17 \pm 4.36 \mathrm{~g}$ weight and 21.24 $\pm 2.08 \mathrm{~cm}$ total length were used as the material in the experiments. The fish were fed once daily at the same hour with commercial fish feed (Pellet No. 2, Pınar, İzmir, Turkey) at 2\% of their total biomass during the study. The water-soluble salt of lead, $\mathrm{Pb}\left(\mathrm{NO}_{3}\right)_{2}$, was used in the study, while EDTA
$\left(\mathrm{C}_{10} \mathrm{H}_{16} \mathrm{~N}_{2} \mathrm{O}_{8}\right)$ was used as the complexing agent. As a result of the literature reviews (Alkahemal-Balawi et al., 2011; BawaAllah and Saliu, 2015) and preliminary studies, non-lethal concentrations of both lead and EDTA (1.0 and 2.0 ppm Pb; 2.0 and $4.0 \mathrm{ppm}$ EDTA) within the specified time periods were determined and utilized.

Five glass aquariums were used in the study to contain 120 $\mathrm{L}$ each of the experimental solutions. Solutions at the concentrations of 1.0 and $2.0 \mathrm{ppm}$ lead were added to the first two aquariums, respectively. To the third and fourth aquariums, solutions of $1.0 \mathrm{ppm}$ lead with $2.0 \mathrm{ppm}$ EDTA and $2.0 \mathrm{ppm}$ lead with $4.0 \mathrm{ppm}$ EDTA were added, respectively. The fifth aquarium contained $120 \mathrm{~L}$ of lead-free tap water and constituted the control. Experiments were carried out in three replicates, and two fish were used in each replicate. Six fish were removed from each aquarium at the ends of the seven-, fifteen, and thirty-day periods and anesthetized with phenoxy-ethanol ( $1 \mathrm{ml} / \mathrm{L}$ ) (Morgan et al., 1997), and the liver, gill, kidney, brain, and muscle tissues of the fish were dissected separately. In total, 90 fish were used in the experiments. All applicable international, national, and/or institutional guidelines for the care and use of animals were followed. Local ethics committee approval was received.

Table 1. Some physical and chemical properties of the water in the experimental aquariums

\begin{tabular}{ll}
\hline Parameter & Value \\
\hline Temperature & $23 \pm 1^{\circ} \mathrm{C}$ \\
Dissolved Oxygen & $6.47 \pm 0.43 \mathrm{ppm} \mathrm{O}_{2}$ \\
$\mathrm{pH}$ & $8.07 \pm 0.04$ \\
Total Hardness & $259.3 \pm 5.82 \mathrm{ppm} \mathrm{CaCO}_{3}$ \\
Total Alkalinity & $350.41 \pm 1.56 \mathrm{ppm} \mathrm{CaCO}_{3}$ \\
\hline
\end{tabular}

Because the test solutions in the aquariums were subject to time-dependent changes in their concentrations due to evaporation, precipitation, and adhesion to surfaces, a semistatic test was applied, and the test solutions were renewed every two days by appropriate dilutions of the stock solution.

The liver, gill, kidney, brain, and muscle tissue samples that were dissected and used in the metal analysis. Samples were placed in an oven set to $105^{\circ} \mathrm{C}$ for 72 hours, until a fixed weight was attained. Then, a mixture of $2 \mathrm{ml}$ nitric acid $\left(\mathrm{HNO}_{3}, 65 \%\right.$, specific gravity 1.40 , Merck) and $1 \mathrm{ml}$ perchloric acid $\left(\mathrm{HClO}_{4}\right.$, $60 \%$, specific gravity 1.53 , Merck) (Muramoto, 1983) was added on a hot plate set at $120^{\circ} \mathrm{C}$ for eight hours. After the burning process, tissue samples were transferred to polyethylene tubes, their total volumes were adjusted to $10 \mathrm{ml}$ with deionized water, and they were made ready for analysis. The lead content of the tissue samples was determined by ICP-MS. Analysis was carried out in triplicate. Control samples were prepared from IAEA 407 (International Atomic Energy Agency) fish tissue 
homogenate. Detailed results on the amount of lead element obtained from the reference material and LOD-LOQ values given in Table 2. Variance analysis and the Student Newman Keul's (SNK) test were performed by using the SPSS package program for the statistical analysis of data.

Table 2. Validation parameters of the analytical method

\begin{tabular}{ll}
\hline Parameter & Value \\
\hline Trace elements & Lead \\
LOD $\left(\mathrm{ng} \mathrm{g}^{-1}\right)$ & 0.39 \\
LOQ $\left(\mathrm{ng} \mathrm{g}^{-1}\right)$ & 1.21 \\
$\mathrm{R}^{2}$ & 0.9999 \\
Certificated Values Concentration $\left(\mathrm{mg} \mathrm{kg}^{-1}\right)$ & 0.12 \\
Certificated Values & \\
95\% Confidence Interval $\left(\mathrm{mg} \mathrm{kg}^{-1}\right)$ & $0.10-014$ \\
\hline
\end{tabular}

Note: IAEA-407 was used as reference material. LOD $=$ Limit of Detection, LOQ= Limit of Quantification

In the present study on C. gariepinus, no mortality was observed in the fish due to the effects of the determined times and concentrations. At the beginning of the experiments, various behavioral and morphological changes were observed in fish, including lack of nutrients, immobility at the bottom of the aquarium, orientation toward the aquarium surface, and darkening of skin color.

The effect of lead-only concentrations after seven days was increased metal accumulation in the tissues and organs examined when compared to the control ( $p<0.05$, Table 3$)$. At the end of the 7th day, the highest accumulation was in the gill tissue, while the lowest accumulation was in the muscle tissue. The effect of high concentrations of lead combined with EDTA was reduced accumulation of lead in the tissues and organs examined, as compared to the effect of lead only $(p<0.05)$.

The effect of lead-only concentrations of 1.0 and $2.0 \mathrm{ppm}$ for fifteen days increased the metal accumulation in all tissues when compared to the control (Table 4). This increase was significantly higher in liver and gill tissues when compared to that on day 7 ( $p<0.05)$. The effect of a mixture of lead and high concentrations of EDTA for fifteen days resulted in an approximately $60 \%$ reduction in lead accumulation in liver, kidney, and gill tissues when compared to the effect of high concentrations of lead only.

Table 3. Lead accumulation in C. gariepinus under the sole effect of lead and together with EDTA for 7 days ( $\mu \mathrm{gPb} / \mathrm{g}$ d.w.)

\begin{tabular}{|c|c|c|c|c|c|}
\hline Tissue & Liver & Kidney & Gill & Brain & Muscle \\
\hline Concentration & $\bar{X} \pm S_{\bar{x}}^{*}$ & $\bar{X} \pm S_{\bar{x}}^{*}$ & $\bar{X} \pm S_{\bar{x}}^{*}$ & $\bar{X} \pm S_{\bar{x}}^{*}$ & $\bar{X} \pm S_{\bar{x}}{ }^{\star}$ \\
\hline Control & BSL & BSL & BSL & BSL & BSL \\
\hline $1 \mathrm{ppm} \mathrm{Pb}$ & $2.29 \pm 0.09$ as & $14.23 \pm 0.46 \mathrm{bs}$ & $19.54 \pm 0.38 \mathrm{cs}$ & $3.39 \pm 0.30 \mathrm{ds}$ & $0.87 \pm 0.04$ es \\
\hline $2 \mathrm{ppm} \mathrm{Pb}$ & $4.62 \pm 0.28$ at & $14.60 \pm 1.15 \mathrm{bs}$ & $25.23 \pm 1.67 \mathrm{ct}$ & $3.65 \pm 0.33$ as & $0.84 \pm 0.04 \mathrm{ds}$ \\
\hline $1 \mathrm{ppm} \mathrm{Pb}+2$ ppm EDTA & $2.15 \pm 0.35$ as & $13.26 \pm 0.93 \mathrm{bs}$ & $16.10 \pm 0.81 \mathrm{cx}$ & $3.26 \pm 0.24 \mathrm{ds}$ & $1.37 \pm 0.17$ at \\
\hline 2 ppm $\mathrm{Pb}+4$ ppm EDTA & $1.40 \pm 0.18$ ax & $9.72 \pm 0.57 \mathrm{bt}$ & $6.43 \pm 0.86 \mathrm{cy}$ & $2.56 \pm 0.16 \mathrm{dt}$ & $0.21 \pm 0.01 \mathrm{ax}$ \\
\hline
\end{tabular}

Note: $\bar{X} \pm S_{\bar{x}}=$ Arithmetic mean \pm Standard error; BSL $=$ Below Sensitivity Level

${ }^{*}=\mathrm{SNK} ; \mathrm{a}, \mathrm{b}, \mathrm{c}, \mathrm{d}$, e were used to determine the differences between tissues while $\mathrm{s}, \mathrm{t}, \mathrm{x}$, and y were used to determine the differences between concentrations. Different letters indicate statistical differences at $P<0.05$.

Table 4. Accumulation of only lead and lead together with EDTA in C. gariepinus tissues for 15 days ( $\mu \mathrm{gPb} / \mathrm{g}$ d.w.)

\begin{tabular}{|c|c|c|c|c|c|}
\hline \multirow{2}{*}{ Concentration } & \multirow{2}{*}{$\frac{\text { Liver }}{\bar{X} \pm S_{\bar{x}}^{*}}$} & \multirow{2}{*}{$\begin{array}{l}\text { Kidney } \\
\bar{X} \pm S_{\bar{x}}^{*}\end{array}$} & \multirow{2}{*}{$\frac{\text { Gill }}{\bar{X} \pm S_{\bar{x}}{ }^{\star}}$} & \multirow{2}{*}{$\frac{\text { Brain }}{\bar{X} \pm S_{\bar{x}}^{\star}}$} & \multirow{2}{*}{$\frac{\text { Muscle }}{\bar{X} \pm S_{\bar{x}}^{*}}$} \\
\hline & & & & & \\
\hline Control & BSL & BSL & BSL & BSL & BSL \\
\hline $1 \mathrm{ppm} \mathrm{Pb}$ & $6.38 \pm 0.67$ at & $11.84 \pm 0.75 \mathrm{bt}$ & $22.40 \pm 0.48 \mathrm{ct}$ & $3.34 \pm 0.23 \mathrm{dt}$ & $1.38 \pm 0.3 \mathrm{et}$ \\
\hline $2 \mathrm{ppm} \mathrm{Pb}$ & $8.29 \pm 0.39$ ax & $11.80 \pm 1.11 \mathrm{bt}$ & $57.29 \pm 1.73 \mathrm{cx}$ & $2.77 \pm 0.18 \mathrm{dt}$ & $1.58 \pm 0.2 \mathrm{dtx}$ \\
\hline $1 \mathrm{ppm} \mathrm{Pb}+2 \mathrm{ppm}$ EDTA & $4.27 \pm 0.55$ ay & $6.04 \pm 0.36 \mathrm{bx}$ & $13.51 \pm 0.52 \mathrm{cy}$ & $2.59 \pm 0.22 \mathrm{dt}$ & $2.11 \pm 0.2 \mathrm{dx}$ \\
\hline $2 \mathrm{ppm} \mathrm{Pb}+4 \mathrm{ppm}$ EDTA & $2.74 \pm 0.09 \mathrm{az}$ & $4.51 \pm 0.16 \mathrm{bx}$ & $11.71 \pm 0.77 \mathrm{cy}$ & $2.62 \pm 0.36$ at & $0.98 \pm 0.01 \mathrm{dt}$ \\
\hline
\end{tabular}

Note: $\bar{X} \pm S_{\bar{x}}=$ Arithmetic mean \pm Standard error; BSL $=$ Below Sensitivity Level

${ }^{*}=\mathrm{SNK}$; $\mathrm{a}, \mathrm{b}, \mathrm{c}, \mathrm{d}$, e were used to determine the differences between tissues while $\mathrm{s}, \mathrm{t}, \mathrm{x}$, and y were used to determine the differences between concentrations. Different letters indicate statistical differences at $P<0.05$. 
Table 5. Lead accumulation in C. gariepinus under the sole effect of lead and under lead together with EDTA for 30 days ( $\mu g \mathrm{~Pb} / \mathrm{g}$ d.w.)

\begin{tabular}{|c|c|c|c|c|c|}
\hline Tissue & Liver & Kidney & Gill & Brain & Muscle \\
\hline Concentration & $\bar{X} \pm S_{\bar{x}}{ }^{\star}$ & $\bar{X} \pm S_{\bar{x}}{ }^{*}$ & $\bar{X} \pm S_{\bar{x}}{ }^{*}$ & $\bar{X} \pm S_{\bar{x}}{ }^{*}$ & $\bar{X} \pm S_{\bar{x}}{ }^{*}$ \\
\hline Control & BSL & BSL & BSL & BSL as & BSL \\
\hline $1 \mathrm{ppm} \mathrm{Pb}$ & $10.46 \pm 0.61$ at & $13.67 \pm 0.43$ at & $47.99 \pm 2.53 \mathrm{bt}$ & $7.91 \pm 0.83 \mathrm{ct}$ & $0.96 \pm 0.09 \mathrm{dt}$ \\
\hline $2 \mathrm{ppm} \mathrm{Pb}$ & $14.97 \pm 1.24 \mathrm{ax}$ & $16.68 \pm 0.80 \mathrm{ax}$ & $74.02 \pm 4.97 \mathrm{bx}$ & $5.49 \pm 0.59 \mathrm{cx}$ & $1.08 \pm 0.08 \mathrm{dt}$ \\
\hline $1 \mathrm{ppm} \mathrm{Pb}+2 \mathrm{ppm}$ EDTA & $5.11 \pm 0.27$ ay & $5.92 \pm 0.12$ ay & $20.85 \pm 2.07$ by & $5.61 \pm 0.52$ ax & $0.96 \pm 0.09 \mathrm{ct}$ \\
\hline $2 \mathrm{ppm} \mathrm{Pb}+4 \mathrm{ppm}$ EDTA & $3.73 \pm 0.41$ ay & $6.51 \pm 0.33$ by & $20.69 \pm 2.54 \mathrm{cy}$ & $3.65 \pm 0.35$ ay & $0.91 \pm 0.02 \mathrm{dt}$ \\
\hline
\end{tabular}

Note: $\bar{X} \pm S_{\bar{x}}=$ Arithmetic mean \pm Standard error; BSL $=$ Below Sensitivity Level

* = SNK; a, b, c, d, e were used to determine the differences between tissues while $\mathrm{s}, \mathrm{t}, \mathrm{x}$, and y were used to determine the differences between concentrations. Different letters indicate statistical differences at $P<0.05$.

The effect of lead at higher concentrations together with EDTA for 30 days significantly increased the accumulation of lead in the tissues and organs examined in comparison to the control and to days 7 and $15(\mathrm{p}<0.05)$ (Table 5). While this increase was parallel to the increase in the lead concentration, the effect of lead together with EDTA reduced the metal accumulation in the examined tissues when compared to the effect of lead only. This decrease was in parallel with the increase in concentration.

\section{Discussion}

The effects of toxic substances, particularly heavy metals, on mortality rate and mortality period in aquatic vertebrates vary depending on the species, the metal, the environmental concentration of the metal, and the duration of exposure. In studies conducted on various fish species, it has been determined that the mortality rate increases in parallel with the increase in the toxin concentration in the environment and the duration of exposure (Abdullah et al., 2007; Gül et al., 2009; Alkahemal-Balawi et al., 2011). In the present study conducted on C. gariepinus, no mortality was observed in the fish under the conditions of time and concentration imposed. That can be explained by the fact that the lead concentrations found in the tissues are not lethal for the subject species in the specified periods.

Fish react by changing their behavior against changing environmental conditions such as pollution or changes in the physical or chemical properties of the water. Those changes include behaviors such as feeding, reproduction, growth, respiration, and movement (Alves and Wood, 2006). In this study conducted with C. gariepinus, behavioral changes such as indifference to food, immobility at the bottom of the aquarium, coordination disorders in swimming movements, and respiration difficulties were observed at the beginning of the lead effect, and the changes disappeared with the prolongation of the effect time. The changes observed in fish behavior at the beginning of the metal effect may result from a reaction to changing environmental conditions, while prolongation of the effect time and return to normal behaviors may be related to adaptation.

In studies conducted with various fish species under both natural and laboratory conditions, it has been found that metal accumulation varied with the tissue and organ (Alves and Wood, 2006; Shukla et al., 2007; Banaee et al., 2013; Ogbuagu et al., 2015). The liver is an important organ that functions in detoxification and biotransformation of xenobiotics, as well as in metabolic events (Van Dyk et al., 2007). It was determined that cadmium in Oreochromis aureus (Gül et al., 2009), lead in Oncorhynchus mykiss (Alves and Wood, 2006), and zinc, cadmium, and copper in Channa punctatus (Shukla et al., 2007) accumulate more in the liver than in other tissues and organs. In the present study conducted with C. gariepinus, the highest accumulation occurred in gill and kidney tissues, followed by liver tissue, under the sole effect of lead. That may be due to the liver being responsible for the detoxification process and the lead concentration failing to exceed its uptake and carrying capacity (Figueiredo-Fernandes et al., 2006; Van Dyk et al., 2007).

In fish, gills take part in respiratory, osmoregulation, and excretion functions. It was determined that lead accumulated most in gill tissue in Carassius auratus (Banaee et al., 2013), C. gariepinus (Kusemiju et al., 2012), and C. catla (Mohanambal and Puvaneswari, 2013), while zinc, copper, and cadmium accumulated most in gill tissue in C. punctatus (Shukla et al., 2007) under the effect of sublethal concentrations. In this study carried out with C. gariepinus, it was found that lead accumulated more in gill tissues than in the kidney, liver, brain, and muscle tissues under the effect of lead only or lead together with EDTA in the determined time periods and concentrations. This high accumulation in the gill tissue may be related to the 
gills interacting directly with the environment. The gills function in excretion, as well as in respiration and osmoregulation (Poleksic and Mitrovic-Tutundzic, 1994; Mazon et al., 2002), and the retention of lead ions by binding them to the mucous membrane covering the gill surface is a defense mechanism (Tao et al., 2000).

The kidney is a multi-function organ that includes hematopoietic, reticuloendothelial, endocrine, and excretory functions in bony fishes (Karaman and Dörücü, 2017). In studies conducted with Prochilodus lineatus (Ribeiro et al., 2014), Tilapia zilli (Karataş and Kalay, 2002) and Cyprinus carpio (Luszczek-Trojnar et al., 2016), lead accumulates most in kidney tissues. On the other hand, in a study conducted with the mentioned species (Al -Balawi et al., 2013) and in the present study, lead was found to accumulate most in gill tissue, followed by kidney tissue. That may be due to the metal being transported to the kidney tissue to be excreted from the body (Clearwater et al., 2002) and retained by binding to metalbinding proteins such as metallothionein in the kidneys (Alves and Wood, 2006).

Unlike other metals, lead has been found to pass through the brain-blood barrier and to accumulate at high concentrations in brain tissue by inhibiting monoamine oxidase and acetylcholine esterase activity (Eisler, 2000). It also inhibits neurotransmitter functions by decreasing gammaaminobutyric acid, cholesterol, and lipid levels (Katti and Sathyanesan, 1986). In a study conducted with Tilapia nilotica and C. carpio, it was found that lead accumulates in both types of brain tissue in higher concentrations than do cadmium, nickel, and chromium (Canlı and Kargın, 1995). As in studies on O. mykiss (Alves and Wood, 2006) and C. catla (Mohanambal and Puvaneswari, 2013), lead accumulations in the present study conducted with C. gariepinus were lower in the brain tissue than in the gill, liver, and kidney tissues under the effect of sublethal concentrations. Lower accumulation in brain tissue may be related to the brain-blood barrier, metal metabolism, and the carrying capacity of tissues (Eisler, 2000; Alves and Wood, 2006).

In studies carried out under various fish species and laboratory conditions (Canlı and Kargın, 1995; Alves and Wood, 2006; Kusemiju et al., 2012; Mohanambal and Puvaneswari, 2013), it was determined that the minimum lead accumulation in tissue was in the muscle tissue. In this study, both under the effect of lead only and lead together with EDTA, the lowest accumulations were in muscle tissue in comparison to other tissues and organs. Lower levels of accumulation in muscle tissue may be closely related to the metabolic function of the tissue or to a shorter exposure period for the accumulation.
Chelating agents form complexes with heavy metals in the environment by adsorption and ion exchange mechanisms, preventing their absorption and accumulation by aquatic organisms and reducing their toxic effects. In C. carpio, lead accumulations in tissues and organs were examined under the sole effect of lead only and of lead together with EDTA, NTA, and DTPA; with chelating agents, lead accumulation was reduced in tissues as compared to the effect of lead only (Muramoto, 1980). It was determined that calcium decreased the tissue lead accumulation in O. mykiss (Alves and Wood, 2006) and the tissue copper accumulation in O. mossambicus (James et al., 1998) as compared to the effect of metals only. In the present study conducted with C. gariepinus, the effect of lead together with EDTA in the experimental times and concentrations decreased lead accumulation in the tissues and organs examined as compared to the effect of lead only. The effect with a chelator may result from decreased accumulation, EDTA complexes with lead, increasing molecular size, and prevention of uptake (Shalaby, 2007).

\section{Conclusion}

As a result, both the effect of lead only and that of lead together with EDTA in C. gariepinus caused lead accumulation in the gill, liver, kidney, brain, and muscle tissues. The highest lead accumulation was in the gill tissue, whereas the lowest was in the muscle tissue. The effect of lead with EDTA reduced the metal accumulation in the tissues examined when compared to the effect of lead only. Therefore, it was concluded that, in $C$. gariepinus, gill tissue is an indicator organ in determining lead toxicity and that EDTA has a reducing effect on lead toxicity.

\section{Acknowledgements}

We would like to thank the Mersin University Scientific Research Projects Unit for supporting the 2017-1-TP2-2071 project. This paper is a part of MSc Thesis of Adeviye Yavuz. An earlier version of this paper was presented at the 19th National Symposium on Fisheries, Sinop, Turkey.

\section{Compliance with Ethical Standards}

\section{Authors' Contributions}

All authors contributed equally to this paper.

\section{Conflict of Interest}

The authors declare that there is no conflict of interest. 


\section{Ethical Approval}

The ethics committee approval was obtained from Mersin University Animal Experiments Local Ethical Committee by decision number 14/45 dated 04/11/2016.

\section{References}

Abdullah, S., Javed, M. \& Javid, A. (2007). Studies on acute toxicity of metals to the fish (Labeo rohita). International Journal of Agriculture and Biology, 9(2): 333-337.

Alkahemal-Balawi, H. F., Ahmad, Z., Al-Akel, A. S., Al-Misned, F., Suliman, El. A. M. \& Al-Ghanim, K. A. (2011). Toxicity bioassay of lead acetate and effects of its sublethal exposure on growth, haematological parameters and reproduction in Clarias gariepinus. African Journal of Biotech, 10(53): 11039-11047. https://doi.org/10.5897/AJB11.1463

Al-Balawi, H. F. A., Al-Akel, A. S., Al-Misned, F., El Amin, M. S., Al-Ghanim, K. A., Mahboob, S. \& Ahmad, Z. (2013). Effects of sub-lethal exposure of lead acetate on histopathology of gills, liver, kidney and muscle and its accumulation in these organs of Clarias gariepinus. Brazilian Archives of Biology and Technology, 56(2): 293302. https://doi.org/10.1590/S151689132013000200015.

Alves, L. C. \& Wood, C. M. (2006). The chronic effects of dietary lead in freshwater juvenile rainbow trout (Oncorhynchus mykiss) fed elevated calcium diets. Aquatic Toxicology, 78: 217-232. https://doi.org/ $\underline{10.1016 / j . a q u a t o x .2006 .03 .005}$

Banaee, M., Haghi, B. N. \& Zoheiri, F. (2013). LC L $_{50}$ and bioaccumulation of lead nitrate $\mathrm{Pb}\left(\mathrm{NO}_{3}\right)_{2}$ in goldfish (Carassius auratus). International Journal of Aquatic Biology, 1(5): 233-239. $\quad$ https://doi.org/10.22034/ ijab.v1i5.153

Bawa-Allah, K. A. \& Saliu, J. K. (2015). Acute toxicity and bioaccumulation patterns of lead and zinc in juveniles of Clarias gariepinus. Journal of Environmental Science Toxicology and Food Technology (IOSR-JESTFT), 9(1): 42-47. https://doi.org/10.9790/2402-09124247

Canl, M. \& Kargin, F. (1995). A comparative study on heavy metal (Cd,Cr, $\mathrm{Pb}$ and $\mathrm{Ni}$ ) accumulation in the tissue of the carp Cyprinus carpio and the nile fish Tilapia nilotica. Turkish Journal of Veterinary and Animal Sciences, 19: 165-171.
Cengiz, E. İ. (2006). Gill and kidney histopathology in the freshwater fish Cyprinus carpio after acute exposure to deltamethrin. Environmental Toxicology and Pharmacology, 22: 200-204. https://doi.org/10.1016/ j.etap.2006.03.006

Cicik, B., Ay, Ö. \& Karayakar, F. (2004). Effects of lead and cadmium interaction on the metal accumulation in tissue and organs of Nile tilapia Oreochromis niloticus. Bulletin of Environmental Contamination and Toxicology, 1(72): 141-148. https://doi.org/ $\underline{10.1007 / \mathrm{s} 00128-003-0252-5}$

Clearwater, S. J., Farag, A. M. \& Meyer, J. S. (2002). Review: Bioavailability and toxicity of dietborne copper and zinc to fish. Comparative Biochemistry and Physiology - Part C, 132: 269-313. https://doi.org/10.1016/S1532$\underline{0456(02) 00078-9}$

Çiftçi, N., Cicik, B., Erdem, C. \& Ay, Ö. (2008). Effects of lead concentrations on sera parameters and hematocrit levels in Anguilla anguilla (Linnaeus, 1758). Journal of Fisheries Sciences, 2(4): 616-622. https://doi.org/ $\underline{10.3153 / \text { jfscom. } 2008025}$

Eisler, R. (2000). Handbook of chemical risk assessment health hazards to humans, plants and animals: Vol 1, United States of America, 844p.

Figueiredo-Fernandes, A., Fontanhas-Fernandes, A., Rocha, E. \& Reis-Henriques, M. A. (2006). The effect of paraquat on hepatic EROD activity, liver and gonadal histology in males and females of Nile tilapia, Oreochromis niloticus, exposed at different temperatures. Archives of Environmental Contamination and Toxicology, 51: 626632. https://doi.org/10.1007/s00244-005-0208-3

Gül, A., Yılmaz, M. \& Işılak, Z. (2009). Acute toxicity of zinc sulphate $\left(\mathrm{ZnSO}_{4} \cdot \mathrm{H}_{2} \mathrm{O}\right)$ to guppies (Poecilia reticulata P.1859). Gazi University Journal of Science, 22(2): 59-65.

James, R., Sampath, K. \& Selvamani, P. (1998). Effect of EDTA on reduction of copper toxicity in Oreochromis mossambicus (Peters). Bulletin of Environmental Contamination and Toxicology, 60: 487-493. https://doi.org/10.1007/s001289900651

Jezierska, B. \& Witeska, M. (2006). The metal uptake and accumulation in fish living in polluted waters. Soil and Water Pollution Monitoring, Protection and Remediation, 3(23): 107-113. https://doi.org/ $\underline{10.1007 / 978-1-4020-4728-2 \quad 6}$ 
Karaman, Z. \& Dörücü, M. (2017). Balıklarda bağışıklık sistemi organları ve histolojisi. International Journal of Pure and Applied Sciences, 3(1): 65-74.

Karataş, S. \& Kalay, M. (2002). Tilapia zilli'nin solungaç, karaciğer, böbrek ve beyin dokularında kurşun birikimi. Turkish Journal of Veterinary and Animal Sciences, 26: 471-477.

Katti, S. R. \& Sathyanesan, A. G. (1986). Lead nitrate induced changes in the brain constituents of the freshwater fish Clarias batrachus (L). Neurotoxicology, 7(3): 47-52.

Kedziorek, M. A. M. \& Bourg, A. C. M. (2000). Solubilization of lead and cadmium during the percolation of EDTA through a soil polluted by smelting activities. Journal of Contaminant Hydrology, 40: 381-392. https://doi.org/ 10.1016/S0169-7722(99)00056-X

Khidr, B. M., Mekkawy, I. A. A., Harabawy, A. S. A. \& Ohaida, A. S. M. I. (2012). Effect of lead nitrate on the liver of the cichlid fish (Oreochromis niloticus): A light microscope study. Pakistan Journal of Biological Sciences, 15(18): 854-862. https://doi.org/10.3923/pjbs.2012.854.862

Kusemiju, V., Patience, A. \& Oluwatoyin, A. J. (2012). Accumulation of lead in the tissues of freshwater catfish Clarias gariepinus exposed to static nominal concentrations of lead nitrate. Agriculture and Biology Journal of North America, 3(12): 510-515. https://doi.org/10.5251/abjna.2012.3.12.510.515

Łuszczek-Trojnar, E., Sionkowski, J., Drazg-Kozak, E. \& Popek, W. (2016). Copper and lead accumulation in common carp females during long-term dietary exposure to these metals in pond conditions. Aquaculture Research, 47: 2334-2348. https://doi.org/10.1111/are.12689

Martinez, C. B. R., Nagae, M. Y., Zaia, C. T. B. V. \& Zaia, D. A. M. (2004). Acute morphological and physiological effects of lead in the neotropical fish Prochilodus lineatus. Brazilian Journal of Biology, 64(4): 797-807. https://doi.org/10.1590/S1519-69842004000500009

Mazon, A. F., Monteiro, E. A. S., Pinheiro, G. H. D. \& Fernandes, M. N. (2002). Hematological and physiological changes induced by short-term exposure to copper in the freshwater fish, Prochilodus Scrofa. Brazilian Journal of Biology, 62(4A): 621-631. https://doi.org/10.1590/S1519-69842002000400010.
Mohanambal, R. \& Puvaneswari, S. (2013). Bioaccumulation of lead in various tissues of the freshwater fish Catla catla (Hamilton, 1822). International Journal of Development Research, 3(8): 54-60.

Morgan, J. D., Sakamoto, T., Grau, E. G. \& Iwama, G. K. (1997). Physiological and respiratory responses of the Mozambique tilapia (Oreochromis mossambicus) to salinity acclimation. Comparative Biochemistry and Physiology, 117A(3): 391-398. https://doi.org/ $\underline{10.1016 / S 0300-9629(96) 00261-7}$

Muramoto, S. (1980). Effects of complexans (EDTA, NTA and DTPA) on the exposure to high concentrations of cadmium, copper, zinc and lead. Bulletin of Environmental Contamination and Toxicology, 25: 941946. https://doi.org/10.1007/BF01985635

Muramoto, S. (1983). Elimination of copper from Cucontaminated fish by long term exposure to EDTA and freshwater. Journal of Environmental Science and Health, 18(3): 455-461. https://doi.org/10.1080/ 10934528309375113

Ogbuagu, D. H., Adebayo, E. T., Ayoade, A. A., Ugwu, O. B. \& Mba, D. O. (2015). Lead accumulation in and its haematological effects on African catfish Clarias gariepinus. African Journal of Aquatic Science, 40(2): 201-204. $\quad$ https://doi.org/10.2989/16085914.2015. $\underline{1028325}$

Poleksic, V. \& Mitrovic-Tutundzic, V. (1994). Fish gills as a monitor of sublethal and chronic effects of pollution (pp. 339-352). In: Mulls, R, Llyod (Eds) on freshwater fish. Oxford, London, UK: Fishing News books.

Ribeiro, A. M., Risso, W. E., Fernandes, M. N. \& Martinez, C. B. R. (2014). Lead accumulation and its effects on the branchial physiology of Prochilodus lineatus. Fish Physiology and Biochemistry, 40: 645-657. https://doi.org/10.1007/s10695-013-9873-8

Shalaby, A. M. E. (2007). Effect of EDTA on toxicity reduction of cadmium in relation to growth some haematological and biochemical profiles of Nile tilapia (Oreochromis niloticus). Journal of Fisheries and Aquatic Science, 2(2): 100-109.

Shukla, V., Dhankhar, M., Prakash, J. \& Sastry, K.V. (2007). Bioaccumulation of $\mathrm{Zn}, \mathrm{Cu}$ and $\mathrm{Cd}$ in Channa punctatus. Journal of Environmental Biology, 28(2): 395397. 
Soengas, J. L. \& Aldegunde, M. (2002). Review. Energy metabolism of fish brain. Comparative Biochemistry and Physiology Part B, 131: 271-296. https://doi.org/ $\underline{10.1016 / S 1096-4959(02) 00022-2}$

Tao, S., Li, H., Liu, C. \& Lam, K. C. (2000). Fish uptake of inorganic and mucus complexes of lead. Ecotoxicology and Environmental Safety, 46: 174-180. https://doi.org/ $\underline{10.1006 / \text { eesa.1999.1902 }}$
Van Dyk, J. C., Pieterse, G. M. \& Van Vuren, J. H. J. (2007). Histological changes in the liver of Oreochromis mossambicus (Cichlidae) after exposure to cadmium and zinc. Ecotoxicology and Environmental Safety, 66: 432-440. https://doi.org/10.1016/j.ecoenv.2005.10.012

Vosylienè, M. Z. (1999). The effect of heavy metals on haematological indices of fish (survey). Acta Zoologica Lituanica. Hydrobiologia, 9(2): 76-82. https://doi.org/10.1080/13921657.1999.10512290 